\title{
Standar Kompetensi Lulusan Pendidikan Agama Kristen Berdasarkan Injil Yohanes
}

\author{
Triyono Surahmiyoto \\ Sekolah Tinggi Teologi Kalimantan - Pontianak \\ Korepondensi: yohanessurahmiyoto@gmail.com
}

\begin{abstract}
Abstrak: Standar kompetensi lulusan sudah diberlakukan oleh pemerintah melalui peraturan yang terkait untuk semua untuk semua mata pelajaran/kuliah pada semua jenjang pendidikan. Perlu upaya agar Pendidikan Agama Kristen dapat diselenggarakan dengan tidak kehilangan esensinya. Salah satu bentuk adalah upayanya menelisik standar kompetensi lulusan Pendidikan Agama Kristen berdasarkan Injil Yohanes. Tujuannya adalah untuk mengungkap esensi standar kompetensi lulusan Pendidikan Agama Kristen. Upaya ini dilakukan dengan menggunakan metode hermeneutik. Hasilnya, ditemukan dua model standar kompetensi lulusan pendidikan agama, yaitu standar kompetensi lulusan agama dalam perspektif Yahudi dan standar kompetensi lulusan agama dalam perspektif. Implikasinya bagi pembelajaran Pendidikan Agama Kristen di Indonesia adalah perlu tetap mempertahankan esensi substansi Pendidikan Agama Kristen, mengembangkan kecakapan dalam penyajian materi khususnya berkaitan dengan penggunaan istilah dan bahasa, mempertajam kejelian dalam mengamati lingkungan untuk menciptakan peluang pembelajaran dan meningkatkan kontribusi serta peran aktif pendidik, peserta didik, orang tua dan gereja.
\end{abstract}

Kata kunci: kompetensi lulusan, Pendidikan Agama Kristen, Injil Yohanes

Abstract: Graduate competency standards have been implemented by the government through relevant regulations for all subjects courses at all levels of education. It is necessary to make efforts so that Christian religious education can be organized without losing its essence. One form is his efforts to investigate the competency standards of Graduates of Christian religious education based on the Gospel of John. The goal is to uncover the essence of the standard of competence of Graduates of Christian education. This effort is carried out using hermeneutic methods. As a result, two standard models of competency of religious education graduates were found, namely the standard of competence of religious graduates in the Jewish perspective and the standard of competence of religious graduates in perspective. The implication for the learning of Christian education in Indonesia is to maintain the essence of the substance of Christian religious education, develop proficiency in the presentation of materials especially related to the use of terms and languages, sharpen the skill in observing the environment to create learning opportunities and increase the contribution and active role of educators, learners, parents and the church.

Keywords: graduate competence, Christian Religious Education, Gospel of John 


\section{PENDAHULUAN}

Standar kompetensi lulusan pendidikan di Indonesia sudah ditetapkan dalam Undang Undang Sisdiknas No 20 tahun 2003 pasal 35, Peraturan pemerintah No 19 Tahun 2005 tentang Standar Nasional Pendidikan, Permendiknas No 23 Tahun 2006 tentang Standar Kompetensi Lulusan, PP No. 55 Tahun 2007 tentang Pendidikan Agama dan Keagamaan, UU No 12 Tahun 2012 tentang Perguruan Tinggi, Permendikbud No 20 tahun 2016, Permendikbuddikti No 3 Tahun 2020, PP No. 57 Tahun 2021 Tentang Standar Nasional Pendidikan, BNSP dan peraturan lainnya yang berkaitan dengan standar kompetensi lulusan pendidikan. Standar kompetensi lulusan tersebut diberlakukan pada semua jenjang pendidikan, dan untuk semua mata pelajaran/kuliah, pada mata pelajaran/kuliah pendidikan agama termasuk pada mata pelajaran/kuliah Pendidikan Agama Kristen. Dengan ditetapkannya dan diberlakukannya standar kompetensi lulusan tersebut maka seluruh penyelenggara pendidikan dan satuan pendidikan pada semua jenjang pendidikan secara hukum bertanggung jawab mengimplementasikan proses pembelajaran dengan standar kompetensi lulusan sebagaimana yang telah ditetapkan dalam undang-undang maupun peraturan pendidikan yang sudah berlaku.

Bagi masyarakat Kristen di Indonesia situasi seperti itu disatu pihak menjadi kesempatan yang sangat berharga untuk berperan aktif melalui pendidikan dalam membangun peserta didik kristen menjadi manusia seutuhnya yaitu manusia cerdas yang berilmu, beriman, bertakwa, berahklak mulia dan beradab sebagai warga negara di Negara Kesatuan Republik Indonesia. Tetapi dipihak lain kesempatan tersebut menjadi sebuah tantangan krusial yang mesti dihadapi dan dilaksanakan dengan penuh kecermatan. Tantangan bisa terjadi karena kompleksitasnya peraturan yang berkaitan penyelenggaraan pembelajaran Pendidikan Agama Kristen, sarana prasarana, penyebaran jumlah siswa Kristen, kesadaran hukum pelaksana dan penyelenggara pendidikan pada setiap jenjang pendidikan dan satuan pendidikan. Tetapi tantangan yang lebih serius adalah adanya tuntutan bagi pendidik untuk menyiapkan dan menyampaikan materi sesuai dengan kompetensi inti dan kompetensi dasar untuk mewujudkan standar kompetensi lulusan yang telah ditetapkan oleh pemerintah.

Konsekuensinya, bagi pendidik yang tidak menyiapkan dan menyampaikan materi sesuai dengan ketentuan yang telah ditetapkan oleh pemerintah tentu akan diperhitungkan sebagai pelanggaran hukum yang berlaku dalam dunia pendidikan di Indonesia. Sementara itu pendidik yang menyiapkan dan menyampaikan materi sesuai dengan ketentuan yang telah ditetapkan oleh pemerintah, besar kemungkinan cenderung mengabaikan hakikat Pendidikan Agama Kristen itu sendiri. Pendidikan Agama Kristen bisa menjadi bias dan mengalami polarisasi. Artinya, pendidikan Kristen menjadi pendidikan yang hanya mengurusi pengajaran agama atau iman Kristen di sekolah dan/atau gereja, atau bahwa pendidikan Kristen menjadi pendidikan yang sekedar memfasilitasi pembelajaran di sekolah dan perguruan tinggi dengan ajaran, nilai-nilai iman Kristen dan budi pekerti serta gaya hidup beragama Kristen semata. ${ }^{1}$

Secara deskriptif dalam pembelajaran Pendidikan Agama Kristen memang memperhatikan dan melibatkan unsur filosofis, sosial dan humanis, tetapi secara teologis pada hakikatnya Pendidikan Agama Kristen lebih berfokus pada implementasi karya Allah dalam membangun intimasi persekutuan dan hubungan timbal balik antara Allah dengan manusia sebagai ciptaan dan umat-Nya. Dalam hal ini dari pihak Allah melibatkan unsur penyataan dan pengenalan diri-Nya sebagai Allah yang maha kuasa dan sebagai Tuhan yang berkuasa dan berdaulat atas manusia, sementara itu dari pihak manusia melibatkan unsur kualitas sikap hati nurani masing-masing sebagai pribadi yang berkuasa dan berdaulat dalam kuasa dan kedaulatan Tuhan untuk mengenal, menerima, mengakui dan percaya atau menolak dan

${ }^{1}$ Binsen S. Sidjabat, "Meretas Polarisasi Pendidikan Kristen," Indonesian Journal of Theology 7, no. 1 (2019): 7 24. 
mengabaikan penyataan Allah tersebut. Oleh karena itu secara esensial Pendidikan Agama Kristen sangat perlu memperhatikan standar kompetensi lulusan sebagaimana yang Tuhan Allah nyatakan dalam kitab suci.

Pembahasan perihal Pendidikan Agama Kristen sebenarnya sudah bukan lagi merupakan hal baru. Banyak pakar Pendidikan Agama Kristen yang sudah menuliskan pemikiran dan pandangannya tentang berbagai aspek yang berkaitan erat dengan Pendidikan Agama Kristen. Banyak buku buku yang bernuansa Pendidikan Agama Kristen sudah diterbitkan dan sudah banyak juga artikel, jurnal, prosiding berkaitan dengan Pendidikan Agama Kristen yang dipublikasikan. Namun sejauh ini ulasan pakar Pendidikan Agama Kristen dalam berbagai karya tulisannya baik dalam buku-buku maupun artikel dan jurnal, biasanya pembahasannya sangat luas dan komprehensif sesuai dengan tingkat kepakaran masing-masing. Sejauh ini ulasan dalam berbagai buku, artikel daan jurnal sepertinya belum terdapat tulisan yang membahas secara khusus berkenaan dengan standar kompetensi lulusan Pendidikan Agama Kristen. Padahal standar kompetensi lulusan merupakan salah satu dari delapan unsur Standar Nasional Pendidikan di Indonesia. Oleh karena itu, perihal standar kompetensi lulusan Pendidikan Agama Kristen semestinya mendapat perhatian serius dalam pemikiran, kajian, pembahasan yang berkaitan dengan penyelenggaraan Pendidikan Agama Kristen khususnya di Indonesia.

Berdasarkan permasalahan tersebut maka perlu untuk menelisik kembali penyataan kitab suci khususnya dalam Injil Yohanes tentang standar kompetensi lulusan Pendidikan Agama Kristen yang esensial. Tujuan upaya ini adalah untuk menemukan dan menguraikan gambaran yang konkrit tentang standar kompetensi lulusan dalam Pendidikan Agama Kristen berdasarkan Injil Yohanes serta menguraikan implikasinya dalam pelaksanaan Pendidikan Agama Kristen di sekolah di Indonesia.

\section{METODE}

Penelitian ini termasuk penelitian pustaka pada umumnya, karena itu penelitian dilakukan dengan menggunakan rancangan penelitian kualitatif. Tetapi oleh karena sumber datanya diperoleh dari teks keagamaan dalam hal ini Alkitab, maka penelitian ini dilakukan dengan menggunakan metode hermeneutik. ${ }^{2}$ Yaitu metode penelitian yang biasa dipergunakan di dalam paper penelitian agama yang bertujuan untuk menggali dan mengungkapkan makna dari teks-teks kitab suci. ${ }^{3}$ Untuk itu maka dalam melakukan observasi dan analisa teks berusaha selalu memperhatikan unsur kualitatif-deskriptifteologis. Memperhatikan unsur kualitatif oleh karena menggunakan dokumen literatur dalam hal ini kitab suci sebagai sumber data utama. Memperhatikan unsur penelitian deskriptif oleh karena berusaha menemukan fakta dan data seperti apa adanya yang tersedia dalam teks Alkitab. Kemudian mempertimbangkan unsur teologis untuk memastikan kesinambungan pemaknaan data deskriptif yang telah ditemukan berkaitan dengan karya Allah yang dipresentasikan dalam Alkitab.

\section{PEMBAHASAN}

\section{Selayang Pandang tentang Injil Yohanes}

\section{Injil Yohanes Terakhir Diinspirasikan}

Pada umumnya peneliti Injil Yohanes menyepakati bahwa penulisan Injil Yohanes terjadi pada akhir abad pertama yaitu sekitar tahun 80-100 masehi. ${ }^{4}$ Tenney juga sepakat bahwa Injil Yohanes ditulis menjelang akhir abad pertama di Asia Kecil, mungkin di Efesus, Ketika pertumbuhan gereja mencapai

${ }^{2}$ Andreas B Subagyo, Pengantar Riset Kuantitatif $\mathcal{E}^{2}$ Kualitatif Termasuk Riset Teologi Dan Keagamaan, Pertama. (Bandung: Yayasan Kalam Hidup, 2004), 118.

${ }^{3}$ Sonny Eli Zaluchu, "Metode Penelitian Di Dalam Manuskrip Jurnal Ilmiah Keagamaan," Jurnal Teologi Berita Hidup 3, no. no 2 (2021): 249-266.

${ }^{4}$ Gary M. Burge, "JOHN," in Evangelical Comentary on the Bible, ed. Walter A Elwell, Second. (Michigan, 1990), 843. 
kematangannya, dan sudah timbul kebutuhan akan ajaran yang lebih lanjut tentang kaidah iman. $^{5}$ Sekalipun banyak peristiwa yang dituliskan oleh Yohanes terjadi pada masa kehidupan Yesus, tetapi semua peristiwa yang dikisahkan oleh Yohanes diinspirasikan oleh Allah pada waktu Yohanes menuliskannya. Sesudah peristiwa penginspirasian ini Allah tidak lagi memberikan inspirasi selanjutnya untuk menuliskan kisah-Nya.

Hal itu berarti bahwa semua tulisan Yohanes dalam Injilnya merupakan berita penting dari seluruh peristiwa inspirasi. Tulisan Yohanes memuat berita utama yang menyatakan maksud, kehendak keinginan Allah yang mesti dipahami, dimengerti dan kemudian dilakukan oleh pembaca dalam kehidupannya. Secara teologis, tulisan Yohanes merupakan upaya terakhir dalam karya Allah memperkenalkan kepada manusia bahwa Allah itu Tuhan yang berkuasa dan berdaulat dalam menciptakan, memberkati, menghakimi, menghukum dan menyelamatkan manusia. Tulisan Yohanes merupakan puncak karya Allah membangun relationship dan fellowship antara Allah dengan manusia dan sebaliknya.

Melalui Injil Yohanes, pembaca dapat mengenal bagaimana peran Allah dalam membangun persekutuan dengan manusia dan bagaimana peran manusia dapat menikmati persekutuan dalam keluarga Allah. Melalui Injil Yohanes, pembaca dapat menelisik bagaimana kehidupan manusia beragama dengan begitu terkesan salehnya, dan beranggapan sudah lebih dari cukup untuk membangun hidup dalam persekutuan bersama Allah, tetapi ternyata menurut perspektif Allah hal tersebut merupakan kesalahan fatal dihadapan Allah. Sebaliknya, melalui Injil Yohanes pembaca juga dapat menelisik dan menemukan bagaimana manusia dapat menikmati hidup dalam persekutuan dengan Allah dengan segala berkatberkat-Nya menurut perspektif Allah, namun justru ditentang, ditolak dan tidak dipahami oleh banyak umat. Oleh karena itu perlu kembali menelusuri dan mengungkap kembali

\footnotetext{
${ }^{5}$ Merril C Tenney, Survei Perjanjian Baru, Ketiga. (Malang: Gandum Mas, 1995).236
}

kebenaran dalam Injil Yohanes berkenaan dengan pokok standar kompetensi lulusan dalam Pendidikan Agama Kristen menurut perspektif Allah.

\section{Injil Yohanes Kental dengan Sebutan Guru terhadap Yesus}

Satu hal yang mengesankan dalam Injil Yohanes sebagai inspirasi terakhir adalah penggunaan istilah guru sebagai panggilan terhadap Yesus. Daniel Sutoyo dalam tulisannya secara komprehensif membahas perihal penyebutan guru terhadap Yesus dalam Injil Yohanes sebagai penyebutan yang lebih mendominasi dibanding dalam Injil Matius, Markus dan Lukas. ${ }^{6}$ Kata guru ini secara harfiah berarti orang besarku (my great one), menyatakan satu gelar kehormatan yang diberikan seorang murid kepada seorang guru Taurat, atau para pencari ilmu kepada para bijak. ${ }^{?}$

Istilah guru dalam Injil Yohanes menjadi penting untuk menemukan bentuk hubungan (role) antara umat dengan Yesus pada waktu itu. Setidaknya pada waktu itu umat lebih mengenal Yesus sebagai sosok seorang guru yang menjadi sumber informasi, pengetahuan dan juga kebenaran khususnya berhubungan dengan kehidupan keagamaan. Yesus juga dipanggil sebagai rabi karena Ia mempunyai murid-murid yang mengikuti-Nya, pengajaran, dan teladanNya. ${ }^{8}$ Jiwa keguruan Yesus terkesan radikal, mengundang kontroversial, mengagumkan dan menarik minat untuk belajar bagi kelompok tertentu tetapi di waktu yang sama justru menimbulkan kontroversi, penolakan, pertentangan keras dari kelompok yang lainnya.

Istilah guru dalam Injil Yohanes juga mengungkapkan kedekatan hubungan antara Yesus dengan sekelompok umat yang hatinya terbuka terhadap kebenaran yang disampaikan Yesus dalam pengajaran-Nya. Sekelompok umat

${ }^{6}$ Daniel Sutoyo, "Yesus Guru Agung," Antusias 3, no. 5 (2014): 64-65.

${ }^{7}$ William Barclay, "The Gospel of John Chapters 1 to 7," in The Daily Study Bible Series (Philadelphia: Westminster, 1975), 87.

${ }^{8}$ Christian Jonch, "Yesus sebagai Guru: Studi Injil Yohanes," Veritas 8, no. 2 (2007): 257-276. 
dari berbagai lapisan masyarakat pada waktu itu lebih akrab berkomunikasi, berdialog, bertukar pikiran tentang ajaran kehidupan keagamaan yang selama ini mereka ikuti dan kemudian dapat berkesempatan mendengar pengajaran Yesus, dan dengan terbuka mereka berbicara dan berdiskusi dengan Yesus sebagai guru. Pada masyarakat kelompok ini kemudian memperoleh pencerahan, pembaruan konsep pemikiran tentang keagamaan dan kemudian membarui perilaku kehidupannya sebagaimana konsep keagamaan yang telah mengalami pembaruan tersebut. Ada di antara mereka yang dengan terang-terangan meninggalkan ajaran tradisional, legalisme, ritual mereka, ada yang dengan sembunyi-sembunyi membuat perubahan, dan ada di antara mereka sejak dari awal mendengar pengajaran Yesus sudah menerima tetapi baru kemudian mereka secara terbuka menunjukannya kepada masyarakat luas

Injil Yohanes Memperkenalkan

Standar Kompetensi Lulusan Pendidikan Agama

Penulis Injil Yohanes secara khas menuliskan dua cerita utama tentang kehidupan beragama. Pertama, kehidupan keagamaan menurut versi bangsa Yahudi, dalam hal ini di prakarsai oleh para alim ulama Yahudi, tua-tua Israel, imamimam, ahli Taurat dan anggota mahkamah agama Yahudi dan diikuti oleh sebagian besar masyarakat Yahudi. Kedua, kehidupan beragama menurut versi Yesus yang diprakarsai oleh Yesus sendiri, kemudian diikuti oleh para muridmurid-Nya dan orang percaya pada umumnya dari sebagian kecil bangsa Yahudi itu sendiri.

Sebenarnya dalam kedua versi hidup beragama tersebut memiliki kesamaan harapan yaitu ingin hidup berkenan kepada Allah. Keduanya juga memiliki sikap yang sama dalam hal menghargai kitab Taurat, sebagai landasan untuk kehidupan beragama yang berotoritas. Namun karena pada kedua belah kelompok tersebut memiliki perbedaan cara memahami teks kitab Taurat, maka kedua belah kelompok ini juga berbeda dalam merumuskan, menetapkan dan memperkenalkan standar kompetensi lulusan kehidupan beragama menurut versinya masing-masing. Demikian pula halnya dalam proses pembelajaran pendidikan agama dalam kelompoknya masing-masing, terjadi perbedaan penekanan esensi ajaran sesuai dengan standar kompetensi lulusan masingmasing, sekalipun sama-sama bertolak pada harapan yang sama yaitu berakhlak mulia dan hidup berkenaan kepada Allah.

Melalui cerita pertemuan dua kelompok masyarakat beragama yang dituliskan oleh penulis Injil Yohanes, setidaknya dapat belajar menemukan bagaimana dinamika kehidupan keagamaan sebagai produk dari sistem pembelajaran yang diimplementasikan berdasarkan standar kompetensinya masingmasing. Mengingat hal tersebut maka sangat penting untuk menelisik Injil Yohanes untuk menemukan standar kompetesi lulusan kehidupan keagamaan dan kemudian dapat diimplementasikan dalam Pendidikan Agama Kristen di sekolah secara khusus di Indonesia

\section{Standar Kompetensi Lulusan Pendidikan Agama dalam Perspektif Yahudi}

Injil Yohanes memang bukanlah buku teks bagi pelaksanaan pendidikan agama, tetapi Injil Yohanes merupakan salah satu buku dalam kitab suci yang mengisahkan pengalaman kehidupan beragama sebagai hasil pembelajaran agama dalam lingkungan masyarakat Yahudi. Sekalipun proses pembelajaran agama dalam masyarakat Yahudi tidak dikisahkan secara langsung dalam Injil Yohanes, namun standar kompetensi lulusan pembelajaran agama dalam masyarakat Yahudi tersebut terlihat kental mengikuti alur pelayanan pengajaran Yesus. Dalam pertemuan, diskusi, percakapan, dialog antara orang Yahudi dengan Yesus yang sering terjadi mengenai satu pokok bahasan keagamaan, menyiratkan adanya standar kompetensi lulusan yang diharapkan menjadi capaian dalam sistem pembelajaran agama Yahudi.

Bagi bangsa Yahudi standar kompetensi lulusan inilah menjadi dasar utama argumentasi untuk menguji, menghakimi dan kemudian menganggap Yesus bersalah dan semua ajaran Yesus adalah salah. Demikian juga terhadap semua guru, nabi dan rasul pun juga akan dianggapnya bersalah oleh orang Yahudi, hingga 
layak dihukum bahkan dimatikan apabila melakukan dan mengajarkan kebenaran yang tidak sesuai dengan standar kompetensi lulusan sebagaimana pedoman yang telah menjadi ketetapan dalam pembelajaran agama Yahudi. Orang Yahudi tidak segan untuk menghakimi, menetapkan bersalah dan menghukum bagi siapapun yang melanggar aturan tata kehidupan sebagaimana standar kompetensi lulusan yang diharapkan sebagaimana dalam pembelajaran agama Yahudi. ${ }^{9}$

Berdasarkan dialog, percakapan, diskusi antara orang Yahudi dengan Yesus mengenai satu pokok bahasan keagaman terlihat standar kompetensi lulusan yang diharapkan oleh masyarakat Yahudi dalam pelaksanaan pembelajaran keagamaan. Adapun standar kompetensi lulusan yang dimaksud diantaranya adalah taat mengamalkan hukum moral agama, taat menjalankan hukum ibadah, taat mempelajari kitab suci serta menunjung tinggi nilai keyahudian. Masyarakat Yahudi yang mengikuti pembelajaran agama dan dinyatakan lulus memenuhi standar kompetensi tersebut akan dihargai dan dihormati sebagai orang yang saleh, cerdas, berakhlak mulia, beriman, bertakwa dan hidup berkenan bagi Tuhan.

\section{Ketaatan Mengamalkan Hukum Moral Agama}

Perihal mengamalkan hukum moral agama bagi bangsa Yahudi bukanlah pengalamaan yang baru terjadi pada masa Yesus. Bagi bangsa Yahudi mempelajari Taurat adalah tanda kesalehan, sehingga orang Yahudi selalu meluangkan banyak waktu untuk mempelaajari hukum. ${ }^{10}$ Secara historis, sejak Tuhan mengeluarkan bangsa Yahudi dari Mesir, melalui Musa Tuhan memberikan petunjuk yang berupa aturan atau hukum sebagai landasan untuk berperilaku dan berbudi pekerti di tanah pemukiman baru yang disediakan Tuhan. Sejak saat itu pula para orang tua, tua tua Israel bersama para imam selalu mengajarkan ketetapan Tuhan Allah kepada anak-anak mereka secara turun temurun. Sekalipun

\footnotetext{
${ }^{9}$ Tenney, Survei Perjanjian Baru, 106

${ }^{10}$ Ibid., 123
}

demikian tidak jarang juga, dalam sejarahnya bangsa Israel sering abai terhadap esensi aturan tersebut hingga menjadi rutinitas, legalitas dan sering terjadi berbagai penyimpangan dalam implemetasinya hingga terjadi ketidak adilan, suap dan lain sebagainya. Apabila terjadi hal yang demikian, maka Tuhan memanggil nabinabi-Nya untuk menginvestigasi, menegur, memperingatkan, menghakimi bahkan menyatakan penghukuman atas bangsa Israel.

Budaya mengajarkan dan menanamkan pola hidup sesuai ketetapan dan aturan Tuhan terus berlanjut, dan menjadi tugas para imam, rahib dan rabi hingga pada masa Yesus. Yohanes pun menuliskan dalam Injilnya bagaimana dinamika kehidupan umat Yahudi dalam menerapkan gaya hidup keagamaannya sebagai hasil capaian proses pembelajaran pendidikan agama sesuai dengan standar kompetensi lulusan yang diharapkan baik unsur pengetahuan, ketrampilan maupun sikap. Proses pembelajaran agama tersebut disatu pihak membuahkan ketelitian, ketekunan, kesetiaan, kefanatikan dalam mengajarkan dan mengamalkan hukum moral agamanya, tetapi dipihak lain nampak pula kegagalpahaman mereka terhadap esensi dan hakikat yang terkandung di dalam aturan moral agama tersebut.

Kisah percakapan ahli-ahli Taurat dan orang -orang Farisi dengan Yesus tentang perempuan yang kedapatan berbuat zinah dalam Yohanes 8:1-11, merupakan salah satu contoh menarik bagaimana ketaatan bangsa Yahudi dalam upaya menerapkan hukum moral keagamaan mereka. Memberikan hukuman terhadap perempuan yang kedapataan berbuat zinah merupakan refleksi keberhasilan dari sistem pembelajaran agama dalam tradisi bangsa Yahudi secara turun temurun mengajarkan untuk mengamalkan hukum moral keagamaan berdasarkan kitab Taurat. Setidaknya dengan sistem pembelajaran agama yang berlangsung secara turun-temurun mereka menjadi tahu bahwa zinah itu perbuatan dosa, zinah itu melanggar ketetapan hukum Taurat dan zinah itu perbuatan yang harus dihukum dengan ranjam batu.

Tetapi dipihak lain, Yohanes sebagai penulis teks menyatakan bahwa perilaku ahli ahli Taurat dan orang-orang Farisi tersebut merupakan siasat 
licik mereka sekedar hanya untuk mencobai Yesus (8:6). Upaya menghadirkan perempuan yang ketangkap basah berbuat zinah ternyata mengungkap niat dan sikap hatinurani yang busuk terhadap Yesus yaitu sekedar untuk memperoleh sesuatu untuk menyalahkan-Nya (8:6).

Hal selanjutnya yang perlu diperhatikan dalam percakapan tersebut adalah ketika Yesus menyatakan sikap-Nya terhadap permasalahan yang di sodorkan oleh ahli-ahli Taurat dan orang-orang Farisi terhadap-Nya. Akhirnya ahliahli Taurat dan orang-orang Farisi pun meninggalkan pertemuan tersebut hingga tinggal Yesus dan perempuan. Peristiwa itu mengindikasikan adanya kedangkalan pemahaman tentang zinah, dosa dan penghukuman dalam pemikiran ahli-ahli Taurat, dan orang-orang Farisi.

Kasus serupa juga ditemukan dalam Yohanes 10:33, dimana terjadi percakapan Yesus dengan orang-orang Yahudi perihal hakikat Yesus. Dalam bagian ini ada dua pokok penting yaitu pengetahuan orang Yahudi bahwa Yesus hanya manusia saja, Yesus menyamakan diri dengan Allah, Yesus menghujat Allah dan orang Yahudi siap menerapkan hukum moral keagamaan yaitu merajam Yesus dengan batu. Keinginan orang Yahudi untuk merajam batu terhadap Yesus merupakan refleksi kesadarannya untuk mengamalkan ketaatannya terhadap hukum moral keagamaan. Amalan merajam batu terhadap orang yang menyamakaan diri dengan Allah juga merupakan refleksi dari capaian sistem pembelajaran berdasarkan standar kompetensi lulusan yang diharapkan dalam sistem pembelajaran keagamaan.

Semangat ketaatan bangsa Yahudi mengamalkan hukum moral keagamaan dalam catatan Yohanes terus berlanjut hingga pasal 19:7 pada waktu persidangan Yesus dihadapan Pilatus. Pernyataan tegas orang-orang Yahudi sangat jelas, yaitu kami mempunyai hukum, menurut hukum itu Yesus harus mati dan Yesus menganggap diri-Nya sebagai Anak Allah. Pernyataan yang tegas ini sudah terjadi disaat sidang yang melibatkan semua unsur lapisan masyarakat Yahudi pada waktu itu, tua-tua Israel, Imam-imam dan imam kepala, ahli-ahli Taurat, mahkamah agama dan hampir seluruh masyarakat Yahudi yang terhasut mengadakan demontrasi besar-besaran dihadapan Pilatus.

Peristiwa tersebut setidaknya menggambarkan bagaimana ketaatan bangsa Yahudi dalam mengamalkan hukum moral keagamaannya. Capaian hasil pembelajaran yang selama ini dilaksanakan sungguh berhasil. Bangsa Yahudi menjadi bangsa yang sangat tertib dalam mengamalkan hukum moral agama. Bangsa Yahudi sebagaian besar dapat memutuskan dengan suara bulat hingga memenangkan voting untuk menghukum mati terhadap Yesus.

\section{Ketaatan Mengamalkan Hukum Ibadah}

Ketaatan mengamalkan hukum peribadatan dalam tradisi Yahudi menyiratkan bagaimana suksesi bangsa Yahudi dalam melaksanakan sistem pembelajaran. Pengetahuan, sikap dan perlaku bangsa Yahudi dalam menjalankan peribadatan secara teliti, ketat, tekun sesuai dengan peraturan dan ketentuan setidaknya menggambarkan capaian pembelajaran sesuai dengan standar kompetensi kelulusan yang diharapkan dalam pembelajaran pendidikan agama Yahudi. Beberapa bagian teks dalam Injil Yohanes mulai pasal satu hingga pasal 19 terdapat berbagai kisah yang menyatakan bagimana bangsa Yahudi sangat menghargai hukum peribadatan.

Pertanyaan orang Yahudi kepada Yohanes pembaptis: "Mengapa engkau membaptis jikalau engkau bukan Mesias, bukan Elia, dan bukan nabi yang akan datang?" (1:25), menggambarkan pengetahuan dan ketelitiannya terhadap persoalan baptisan. Demikian juga pernyataan perempuan Samaria terhadap Yesus dalam Yohanes 4:20, setidaknya memperkenalkan bagaimana ketaatan baik orang Samaria maupun orang Yahudi berkenaan dengan tempat pelaksanaan peribadatan masing-masing.

Kasus yang sangat mencolok tentang bagaimana ketaatan orang Yahudi dalam mengamalkan hukum peribadatan dapat juga ditemukan dalam Injil Yohanes 5:10 dan 16. Dalam kedua bagian tersebut sangat nyata bagaimana bangsa Yahudi sangat menghargai dan mematuhi hukum Sabat dalam peribadatan. 
Terjadinya pelanggaran terhadap hukum Sabat bukan saja mengakibatkan datangnya terguran keras, tetapi juga dapat menyebabkan terjadinya penganiayaan bahkan dalam Yohanes 9:16, pelanggaran terhadap Sabat menjadi bukti untuk menghakimi bahwa "orang ini tidak datang dari Allah."

Kisah yang tidak kalah pentingnya juga terdapat dalam Yohanes 19:42, yaitu kisah prosesi penguburan Yesus. Nikodemus dan Yusuf dari Arimatea harus segera bertindak untuk melakukan penguburan mengingat sudah tiba waktunya persiapan peribadahan paskah dalam tradisi Yahudi. Keduanya adalah muridmurid Yesus yang sangat paham dengan hukum peribadatan dalam tradisi Yahudi. Karena itu segera bertindak untuk melaksanakan prosesi penguburan Yesus. Dalam hal ini nyata bagaimana proses pembelajaran dilaksanakan dengan standar kompetensi lulusan yang diharapkan hingga menghasilkan lulusan yang kompeten dalam mentaati hukum peribadatan.

\section{Ketaatan Mempelajari Kitab Suci}

Ketaatan mempelajari Kitab Suci merupakan standar lulusan yang penting untuk dicapai dalam sistem pembelajaran bangsa Yahudi. Yesus sendiri mengakui ketaatan bangsa Yahudi dalam hal menyelidiki Kitab-kitab Suci. Menurut Yesus, ketaatan bangsa Yahudi dalam menyelidiki Kitab Suci berhubungan erat dengan pengharapan mereka untuk memperoleh hidup yang kekal (5:39-40). Dipihak lain, ketaatan menyelidiki Kitab Suci bagi bangsa Yahudi sangat erat berhubungan dengan pengayaan pengetahuan hingga memudahkan bagi orang -orang Yahudi untuk menguji keabsaahan berbagai informasi yang berkembang dalam masyarakat tentang suatu ajaran tertentu $(7: 41,42)$.

Kepiawaian menyelidiki Kitab Suci juga menjadi suatu kompetensi yang sangat diharapkan dalam proses pembelajaran nampak dalam kisah selanjutnya yang dituliskan Yohanes dalam pasal 7:45-52. Percakapan orang-orang Farisi dengan Nikodemus bukan saja mendiskusikan persoalan hukum tetapi juga menyatakan peran pentingnya kompetensi dalam menyelidiki Kitab Suci. Kemampuan menyelidiki
Kitab Suci sangat memperlengkapi seseorang dengan pengetahuan yang bermanfaat dalam mengevaluasi, menguji dan mengkaji suatu pokok permasalahan yang terjadi secara khusus berkenaan dengan ajaran yang berkembang. Pengetahuan dari Kitab Suci sangat berguna untuk menyatakan keabsahaan suatu informasi 9:29.

Ketataan Menjunjung Tinggi Nilai Keyahudian

Menjunjung tinggi nilai keyahudian merupakan sifat khas dalam kehidupan bangsa Yahudi. Peran seperti ini sebenarnya kewajiban setiap orang Yahudi dalam komunitasnya masing masing. Beberapa bagian kisah yang ditulis Yohanes dalam Injilnya menyatakan sikap ketaatan umat Yahudi dalam menjunjung tinggi nilai keyahudian dalam bangsa ini. Hal ini tentu menjadi sebuah capaian yang sangat diharapkan dalam sistem pembelajaran yang berlangsung dalam masyarakat Yahudi.

Pertayaan orang Yahudi tentang Yesus bahwa Yesus adalah anak Yusuf, dan pengenalannya terhadap ibu Yesus dalam 6:42, menyiratkan adanya pengakuan orang-orang Yahudi bahwa Yesus juga orang Yahudi. Jiwa keyahudian orang sebagai orang Israel juga Nampak dalam pengakuannya bahwa kami adalah keturunan Abraham dan tidak pernah menjadi hamba siapapun dalam Yohanes 8:3 dan 39. Ajaran turun temurun yang ditanam dalam kehidupam masyarakat Yahudi membuahkan jiwa nasionalismenya sebagai keturunan Abraham.

Selanjutnya ketaatan orang Yahudi terhadap nilai keyahudiannya juga mampak dalam pengakuannya bahwa kami adalah murid-murid Musa dalam Yohanes 9:28. Sebagai murid Musa merupakan kebanggaan tersendiri bagi bangsa Yahudi, sebagai orang-orang yang menghormati dan menjunjung tinggi hukum, aturan, tata tertib kehidupan sebagaimana yang diajarkan Musa sejak nenek moyang mereka. Karena itu mereka terus memelihara ketaatannya kepada nilai-nilai keyahudiannya itu.

Yohanes juga menuliskan kisah bangsa Yahudi yang sangat menjunjung tinggi nilai keyahudiannya dalam pasal 19:40. Yohanes menuliskan bahwa sebagai orang Yahudi, Yusuf 
dari Arimatea dan Nikodemus beserta beberapa orang Yahudi lainnya mengambil mayat Yesus, mengapaninya dengan kain lenan dan membubuhinya dengan rempah-rempah menurut adat orang Yahudi bila menguburkan mayat. Sungguhpun mereka tidak sanggup membela Yesus dalam persidangan dan kemudian kalah dengan voting, namun sebagai orang Yahudi mereka masih memiliki kesempatan menunjukan kepedulian dan ketaatannya terhadap nilai-nilai keyahudian.

\section{Standar Kompetensi Lulusan Pendidikan Agama dalam Perspektif Yesus}

Injil Yohanes bukan hanya secara tersirat mengungkapkan adanya standar kompetensi lulusan pendidikan agama dalam perspektif Yahudi, tetapi justru secara tersurat Injil Yohanes memperkenalkan standar kompetensi lulusan pendidikan agama dalam perspektif Yesus. Berdasarkan inspirasi yang diterimanya, Yohanes secara cermat menuliskan alur gagasan dalam Injilnya untuk memperkenalkan standar kompetensi lulusan pendidikan agama dalam perspektif Yesus. Yohanes sebagai rasul yang memiliki kesempatan hidup hingga suntuk umur, dapat menyaksikan secara langsung tanda tanda adanya pengajaran agama dengan standar kompetensi lulusan yang sudah mulai bias pada masa peralihan generasi kehidupan keagamaan.

Menurut catatan sejarah, sepertinya pada masa peralihan generasi kehidupan keagamaan pada waktu itu sudah mulai ada tanda-tanda bertumbuhnya pengajaran filsafat agnostik, yaitu corak kehidupan keagamaan yang lebih mengutamakan peranan akaliah manusia semata ${ }^{11}$. Sementara itu memang perlu diakui juga bahwa pada kenyataannya cerita perihal Yesus secara lisan tentunya sudah mulai memudar di kalangan generasi muda. Cerita perihal Yesus sudah mulai menjadi tulisan sakral dan antik yang dikoleksi dan diperlukan hanya bagi lapisan masyarakat tertentu di kalangan kaum agamawan. Kalaupun pada masa itu cerita perihal Yesus secara lisan masih terus dikisahkan dan ditularkan di kalangan masyarakat luas,

\footnotetext{
${ }^{11}$ Ibid.
}

kemungkinan cerita tentang Yesus pun sudah ditanggapi dengan sudut pandang yang berbeda sehingga memungkinkan terjadinya pemaknaan yang menyimpang dari makna orisinilnya.

Oleh karena itu Yohanes sebagai rasul perlu menuliskan kembali cerita perihal Yesus dengan pokok bahasan yang sangat khas sebagai wasiat bagi generasi selanjutnya. Yohanes tidak lagi menuliskan secara deskripsi detil semua cerita tentang Yesus, melainkan memilihnya dengan cermat beberapa cerita dari peristiwa penting dalam pelayanan Yesus. Kemudian Yohanes menulis semua cerita tersebut dan menyusunnya menjadi alur cerita dengan kronologi waktu kejadiannya masing-masing dengan maksud untuk menegaskan makna teologis yang terkandung dalam cerita tentang Yesus tersebut. Itulah sebabnya tulisan Yohanes lebih mengutamakan nuasa pengajaran bagi pembaca untuk memahami bagaimana standar kompetensi kehidupan yang benar menurut perspektif Allah, dari pada sekedar menyuguhkan kembali cerita-cerita yang berkaitan dengan Yesus dan kehidupan dengan standar kompetensi hanya untuk memenuhi hukum keagamaan.

Berdasarkan penelusuran teks dalam Injil Yohanes, standar kompetensi lulusan pendidikan agama dalam perspektif Allah yang dimaksud adalah mengenal Yesus dan karya-Nya, mengenal manusia dan karyanya, mengenal Bapa dan karya-Nya, mengenal Roh Kudus dan karyaNya serta mengenal Iblis dan karyanya. Hampir semua standar kompetensi lulusan pendidikan agama tersebut sudah diperkenalkan secara langsung oleh Yohanes sebagai pokok bahasan pada bagian pendahuluan Injil Yohanes. yang kemudian dibuktikan dengan cerita-cerita di bagian selanjutnya dalam tulisannya.

\section{Memperkenalkan Yesus dan Karya-Nya}

Satu pokok bahasan utama yang menjadi prioritas sebagai standar kompetensi lulusan dalam pendidikan agama adalah mengenal Yesus dan karya-karya-Nya. Oleh karena itu perihal Yesus dan karya-karya-Nya merupakan pokok bahasan utama secara keseluruhan dalam tulisan Injil Yohanes. Bahkan dalam Injil Yohanes, 
Tuhan tidak lagi menginpirasikan secara detil perihal Yesus untuk dituliskan baik berkenaan silsilah, masa kanak-kanak maupun berbagai peristiwa pelayanan secara panjang lebar. Tetapi justru Tuhan menginspirasikan kepada Yohanes untuk menuliskan semua hal ikhwal Yesus dari perspektif teologi yaitu berkenaan dengan kuasa dan kedaulatan Yesus yang memperkenalkan bahwa Ia adalah TUHAN. Itulah sebabnya semua cerita yang diinspirasikan kepada Yohanes untuk dituliskan selalu memperkenalkan kuasa dan kedaulatan Yesus dalam kaitannya dengan penciptaan, pemberkatan, pemberdosaan, penghakiman, penghukuman maupun penyelamatan.

Tentunya melalui tulisan Yohanes, Tuhan bermaksud agar pembaca bukan hanya mengenal Yesus sebagai Guru berkarisma yang mumpuni dalam pelbagai pengetahuan dan kuasa untuk menolong dan memenuhi segala keperluan manusia. Tetapi lebih daripada itu melalui tulisan Yohanes ini Tuhan menginginkan agar manusia sebagai pembaca dapat mengenal bahwa Yesus itu adalah Tuhan yang berkuasa dan berdaulat atas manusia, Iblis dan alam semesta.

Oleh karena itu pada bagian pendahuluan Yohanes sudah memperkenalkan secara singkat keberadaan, kuasa, karya dan hubungan Yesus dengan alam semesta dan manusia. Pada bagian selanjutnya Yohanes menuliskan tentang Yesus dan karya-Nya dengan berbagai istilah khas yang bernuansa keyahudian.

\section{Memperkenalkan Manusia dan Karyanya}

Pokok bahasan selanjutnya yang Yohanes ingin perkenalkan sebagai standar kompetensi lulusan dalam pendidikan agama dalam Injil Yohanes adalah tentang manusia dan karyanya. Pokok bahasan ini menjadi bagian yang sangat penting mengingat tujuan utama Tuhan menciptakan manusia adalah untuk membangun intimasi persekutuan dan hubungan timbal balik antara Allah dengan manusia. Tetapi dalam membangun intimasi persekutuan dan hubungan timbal balik tersebut Tuhan berhadapan dengan kenyataan jati diri manusia sebagai pribadi yang telah memiliki kuasa dan kedaulatan yang Tuhan telah karuniakan untuk berkarya secara kreatif dengan memberdayakan akal budinya untuk menjalan mandat Tuhan. Sementara itu, manusia dalam melaksanakan mandat Tuhan yang telah diterimanya memiliki kesempatan memilih dan memutuskan berdasarkan kuasa dan kedaulatannya untuk melakukan berdasarkan "apa yang Allah pikirkan” atau melakukan berdasarkan "apa yang dipikirkannya sendiri”

Itulah sebabnya sekalipun Yohanes menuliskan bahwa pada dasarnya manusia itu diciptakan oleh Allah, tetapi selanjutnya Yohanes menuliskan bahwa ternyata dalam kehidupannya, manusia terdapat dua kualifikasi yang berbeda sejak pada bagian awal penulisannya, yaitu kualifikasi sebagai manusia yang tidak mengenal, tidak percaya dan tidak ada kasih akan Allah dan kualifikasi manusia yang mengenal, percaya, menerima dan mengasihi Allah. Pada bagian bagian berikutnya Yohanes menuliskan berbagai kisah yang menggambarkan perilaku manusia dalam dua kualifikasi tesebut dengan segala dinamikanya.

\section{Memperkenalkan Bapa dan KaryaNya}

Sesudah Yohanes memperkenalkan dua standar kompetensi lulusan dalam pendidikan agama, Yohanes juga memperkenalkan perihal Bapa dan karya-Nya sebagai kompetensi lulusan yang perlu disampaikan dalam pendidikan agama. Standar Kompetensi lulusan ini juga menjadi bagian yang sangat penting mengingat keberadaan Bapa dan hubungannya baik dengan Yesus, manusia dan bahkan dengan Roh Kudus. Pada bagian permulaan tulisannya Yohanes sudah memperkenalkan baik Bapa dan Roh Kudus secara bersamaan dalam kisah pembaptisan Yesus oleh Yohanes pembaptis yang menjadi kesaksian bagi manusia pada waktu itu.

Selanjutnya pada bagian bagian berikutnya secara berulang kali Yohanes menyisipkan dalam tulisannya kisah kisah yang berkaitan dengan Bapa dan karya-Nya. Pokok bahasan ini pada kenyataannya menimbulkan kontroversi dikalangan pada pemimpin bangsa Yahudi yang 
tidak mengenal jati diri Yesus dalam kaitannya dengan Bapa.

\section{Memperkenalkan Roh Kudus dan Karya-Nya}

Sebagai pokok bahasan yang tidak kalah pentingnya, Yohanes juga memperkenalkan Roh Kudus dan karya-Nya. Sekalipun terkesan tidak banyak bagian dalam Injilnya yang menyatakan perihal Roh Kudus dan karya-Nya, namun hakikat Roh Kudus diperkenalkan pada beberapa bagian dengan peran yang sangat penting dan diperlukan bagi manusia.

Sesudah pada bagian permulaan tulisannya Yohanes memperkenalkan karya Roh Kudus bersama Bapa dan Yesus pada peristiwa pembaptisan, selanjutnya Yohanes memperkenalkan karya Roh Kudus berkenaan dengan karya-Nya memelihara orang-orang percaya. Satu hal yang penting berkenaan Roh Kudus dalam Injil Yohanes adalah penyebutan terhadapNya, Roh Kudus disebut sebagai Penghibur pada pasal 14:26; 16:7, Roh Kudus disebut sebagai Roh Kebenaran pada pasal 14:17;16:13 dan Roh Kudus disebut sebagai Penolong pada pasal 14:4.

\section{Memperkenalkan Iblis dan Karyanya}

Sekalipun terkesan kurang mendapat perhatian dalam pembahasan pada tulisannya, tetapi tentang Iblis dan karyanya juga menjadi bagian dari standar kompetensi lulusan yang Yohanes perkenalkan untuk dipahami oleh para pembaca kitab Injil Yohanes. Setidaknya ada beberapa kali Yohanes memperkenalkan perihal Iblis dalam tulisannya. Pada pasal 6:7 Yohanes mengutip perkataan Yesus berhubungan dengan pemilihan dua belas murid, dimana salah satu murid ternyata memiliki karakter Iblis menurut penilaian Yesus. Kemudian dalam Yohanes pasal 8:44 Yohanes juga mengutip pernyataan Yesus ketika menilai kualitas rohani orang-orang Yahudi sebagai anak buah Iblis. Selanjutnya Yohanes menegaskan tentang karya Iblis dalam hubungannya dengan Yudas Iskariot mengkhianati Yesus; membisikan rencana pada pasal 13:2 dan merasuki Yudas Iskariot pada pasal 13:27.

\section{Implikasi Standar Kompetensi Lulusan Berdasarkan Injil Yohanes bagi Pembelajaran Pendidikan Agama Kristen di Sekolah}

Pada bagian pendahuluan artikel ini penulis sudah memperkenalkan permasalahan serius berkenaan dengan penerapan standar kompetensi lulusan pada mata pelajaran/kuliah Pendidikan Agama Kristen di sekolah pada semua jenjang pendidikan di Indonesia. Terlepas adanya kesan negatif tentang penetapan dan pemberlakuan standar kompetensi lulusan pada mata pelajaran/kuliah Pendidikan Agama Kristen di sekolah pada semua jenjang pendidikan, namun satu hal yang positif adalah masih adanya kesempatan dan peluang terbuka bagi umat Kristen di Indonesia untuk berperan aktif dalam memperlengkapi peserta didik kristen melalui Pendidikan Agama Kristen di sekolah-sekolah pada semua jenjang pendidikan dalam perlindungan hukum yang berlaku.

Persoalan selanjutnya adalah bagaimana umat Kristen mendayagunakan kesempatan dan peluang tersebut supaya menjadi kesempatan berdaya guna untuk memperlengkapi peserta didik kristen melalui Pendidikan Agama Kristen. Berbagai tantangan, hambatan, kesulitan dari pelbagai aspek akan selalu ada dan sepertinya akan selalu menjadi momok yang menghantui perjuangan menunaikan tugas pembelajaran Pendidikan Agama Kristen melalui sekolah pada semua jenjang pendidikan.

Peran masyarakat kristen tentunya bukan untuk menghadapi dan menyelesaikan semua persoalan yang ditemukan di lapangan pelaksanaan Pendidikan Agama Kristen di sekolah pada semua jenjang pendidikan tersebut. Peran masyarakat kristen adalah mensiasati situasi dan kondisi di lapangan agar implementasi Pendidikan Agama Kristen dapat terus berlangsung termasuk dalam hal mencermati dengan arif, bijak, cerdik dan tulus bagaimana menerapkan standar kompetensi lulusan pada mata pelajaran/kuliah Pendidikan Agama Kristen tersebut.

Berdasarkan survei pada kitab Injil Yohanes perihal standar kompetensi lulusan pada mata pelajaran/kuliah Pendidikan Agama Kristen, setidaknya ada beberapa gagasan yang perlu 
dipertimbangkan sebagai implikasi dalam Pendidikan Agama Kristen.

\section{Mempertahankan Esensi Substansi Pendidikan Agama Kristen}

Perbedaan mendasar antara pandangan orang Yahudi dan Yesus dalam hal standar kompetensi lulusan pendidikan agama berdasarkan tulisan Yohanes dalam Injilnya adalah pada esensi substansi pendidikan agama itu sendiri. Sekalipun pada kedua belah pihak sama-sama sebagai orang Yahudi, berkiblat pada penyelidikan kitab suci yang sama, berorientasi pada penyembahan dan berbakti kepada Allah yang sama namun keduanya berbeda dalam hal pendekatan dan pemaknaan berita yang dituliskan dalam kitab suci. Orang Yahudi cenderung menggunakan pendekatan dan pemaknaan berita yang dituliskan dalam kitab suci secara deskriptif harfiah sehingga berimbas pada penerapan perilaku kehidupan yang cenderung legalitas dan formalitas yang justru mengungkapkan kebobrokan moral keimanannya kepada Allah menurut penilaian Yesus. Berbeda halnya dengan Yesus dalam memahami apa yang tertulis dalam kitab suci dengan menggunakan pendekatan dan pemaknaan dari aspek teologis yang berimbas pada penerapan perilaku kehidupan yang cenderung praktis, luwes dan sederhana, namun justru dipandang salah oleh para pemimpin Yahudi pada umumnya. Dalam hal seperti ini Yesus pun tidak bergeming dan terus melanjutkan pengajaran-Nya dengan terus mempertahankan esensi subatansi pendidikan agama sebagaimana yang dimaksudkan Tuhan Allah.

Alangkah bijaknya apabila dalam implementasi Pendidikan Agama Kristen di sekolah pada semua jenjang pendidikan di Indonesia, terus berorientasi pada esensi substansi Pendidikan Agama Kristen sebagaimana yang Tuhan inginkan. Upaya untuk mewujudkan Pendidikan Agama Kristen seperti ini memang tidaklah mudah, tentunya banyak faktor yang dapat mempengaruhi efektivitas pelaksanaan Pendidikan Agama Kristen tersebut selain faktor pendidik dan tenaga kependidikan. Seiring dengan berjalannya waktu, upaya tersebut dapat dimulai dari kesadaran pendidik dan tenaga kependidikan terhadap esensi susbtansi dalam Pendidikan Agama Kristen.

\section{Mengembangkan Kecakapan dalam Penyajian Materi Khususnya Berkaitan dengan \\ Penggunaan Istilah dan Bahasa}

Belajar dari kisah pembajaran agama dalam Injil Yohanes baik dari perspektif Yahudi maupun pespektif Yesus tentang standar kompetensi lulusan pendidikan agama, sepertinya ada masalah serius berkenaan dengan penggunaan istilah dan bahasa. Pada dasarnya kedua belah pihak memiliki bahasa, kosa kata dan beberapa istilah teologi yang sama dalam penyebutan dan penggunaannya, namun pada kedua belah pihak memiliki perbedaan yang tajam dalam hal pemaknaan dan pendiskripsiannya yang pada akhirnya menimbulkan perbedaan juga dalam hal menemukan hikmah dan aplikasinya dalam perilaku kehidupan di tengah masyarakat pada kedua belah pihak.

Ironisnya, perbedaan pemahaman, pemaknaan dan pendiskripsian suatu istilah pada kedua belah pihak berlanjut dengan retaknya hubungan dan menimbulkan rasa pemusuhan yang tajam dari pihak orang Yahudi terhadap Yesus dan murid-murid-Nya. Yesus memang sudah memberitahukan tentang hal tersebut 2 atau 3 kali kepada murid-murid-Nya sebelum akhirnya kemarahan orang Yahudi memuncak hingga menyalibkan Yesus. Tetapi peristiwa tersebut sungguh ironis karena para pelaku dalam peristiwa tersebut adalah orangorang Yahudi yang notabene kaum rohaniawan dan agamawan yang gagal paham dalam memaknai beberapa istilah teologi dalam agamanya.

Bertolak dengan peristiwa tersebut alangkah baiknya apabila pendidik dan tenaga kependidikan dalam melaksanakan Pendidikan Agama Kristen di sekolah pada semua jenjang pendidikan perlu memperhatikan bahasa dan penggunaan beberapa istilah teologi yang memiliki kesamaan dalam penyebutan namun 
berbeda dalam pemaknaan dan pendeskripsiannya. Hal ini sangat penting bukan hanya untuk menghindari terjadinya konflik brutal baik antar agama maupun inter agama, tetapi juga untuk meluruskan kembali makna yang sebenarnya sesuai dengan perspektif Tuhan.

\section{Mempertajam Kejelian dalam Mengamati Lingkungan untuk Menciptakan Peluang Pembelajaran}

Masyarakat Kristen pada dasarnya secara hukum memiliki kesempatan dan dapat memberdayakannya sebagai peluang untuk mengimplementasikan Pendidikan Agama Kristen di sekolah pada semua jenjang pendidikan. Di samping memiliki jaminan perlindungan hukum, masyarakat kristen khususnya pendidik dan tenaga kependidikan memiliki berbagai kemudahan termasuk dalam hal standar kompetensi lulusan dalam Pendidikan Agama Kristen hingga sampai kepada kompetensi inti dan kompetensi dasar serta silabus. Semua kelengkapan dalam pembelajaran tersebut telah disiapkan oleh kementrian yang terkait beserta seluruh jajarannya guna memperlancar efektivitas dan efesisensi kerja pelaksanaan pembelajaran Pendidikan Agama Kristen di sekolah. Namun mengingat minimnya jumlah peserta didik Kristen dan penyebarannya yang sporadis menyebabkan banyak beban dan kendala dalam melaksanakan Pendidikan Agama Kristen di sekolah. Ada begitu banyak sekolah sekolah baik negeri maupun swasta selain sekolah keagamaan yang memiliki jumlah peserta didik Kristen sangat sedikit sehingga tidak dapat melaksanakan pembelajaran Pendidikan Agama Kristen secara optimal dan bahkan terabaikan begitu saja.

Mengingat hal seperti itu maka pendidik, tenaga kependidikan kristen sebaiknya mempertajam kejelian dalam mengamati lingkungan untuk menciptakan peluang pembelajaran Pendidikan Agama Kristen di sekolah, teristimewa pada jenjang pendidikan dasar dan menengah. Memang harus diakui bahwa seandainya dapat menemukan kesempatan dan peluang pun beban untuk melakukan pembelajaran Pendidikan Agama
Kristen tersebut sangat berat, apa lagi di daerah pelosok pedesaan. Namun demikian alangkah naifnya juga jika kesempatan dan peluang yang ditemukan tersebut diabaikan dan tidak diberdayagunakan sebagai wahana pembelajaran Pendidikan Agama Kristen.

Meningkatkan Kontribusi dan Peran Aktif Pendidik, Peserta Didik, Orang Tua dan Gereja

Implikasi terakhir yang perlu dipahami setelah menelisik standar kompetensi lulusan pendidikan agama dalam Injil Yohanes adalah meningkatkan kontribusi dan peran aktif pendidik, peserta didik, orang tua dan gereja pada lingkungan masing-masing. Salah satu bentuk kontribusi yang paling sederhana dan mudah dilakukan adalah saling berbagi informasi berkenaan dengan kenyamanan aktivitas peserta didik Kristen dalam menikmati pembelajaran Pendidikan Agama Kristen di sekolah masing-masing. Hal ini penting untuk memastikan terpenuhi dan tidaknya hak dan kewajiban belajar peserta didik kristen khususnya dalam mata pelajaran/kuliah Pendidikan Agama Kristen di sekolah masingmasing dan untuk memastikan bagaimana upaya pertolongan yang perlu dilakukan apabila hak dan kewajiban peserta didik kristen belum terpenuhi.

Oleh karena itu sangat diperlukan kesadaran, perhatian dan kepedualian dari berbagai lapisan masyarakat Kristen untuk saling berkomunikasi berbagi informasi guna memberdayakan kesempatan dan peluang pembelajaran Pendidikan Agama Kristen pada lingkungan terdekat masing-masing. Dengan berpedoman pada standar kompetensi lulusan sebagaimana yang ditemukan dalam penelusuran Injil Yohanes, setidaknya Pendidikan Agama Kristen dapat diselenggarakan tanpa kehilangan esensi substansinya sekalipun dalam pelaksanaannya belum dapat diselenggarakan secara maksimal memenuhi standar nasional pendidikan di Indonesia. 


\section{KESIMPULAN}

Standar kompetensi lulusan Pendidikan Agama Kristen masih menjadi ketetapan dalam undang undang dan peraturan serta masih diberlakukan untuk membantu mewujudkan tujuan pendidikan nasional di Indonesia. Seperti apapun bentuk standar kompetensi lulusan dalam Pendidikan Agama Kristen, tetap memberi kesempatan bagi umat Kristen untuk berperan aktif dan berkontribusi melalui pembelajaran kepada peserta didik kristen sekolah pada semua jenjang pendidikan dalam membangun manusia seutuhnya yang cerdas, berakhlak mulia, berbudi pekerti luhur, beriman dan bertakwa kepada Tuhan. Peran utama bagi pendidik, tenaga kependidikan dan pengguna adalah mencermati, memahami serta mensiasati setiap kesempatan menjadi peluang untuk melaksanakan pembelajaran Pendidikan Agama Kristen di sekolah. Prioritaskan esensi substansi dalam Pendidikan Agama Kristen sebagaimana maksud dan keinginan Tuhan yaitu pemberitaan perihal Yesus dan karya-Nya bagi manusia. Terus berjuang mengembangkan kecakapan dalam penyajian materi khususnya berkaitan dengan penggunaan istilah dan bahasa agar tidak terjebak pada pemahaman yang dangkal dan berakibat fatal pada gagal paham. Pertajam kejelian dalam mengamati lingkungan untuk menciptakan peluang pembelajaran. Lanjutkan peningkatan sinergi pengabdian, kontribusi dan peran aktif pendidik, peserta didik, orang tua dan gereja.

\section{KEPUSTAKAAN}

Barclay, William. "The Gospel of John Chapters 1 to 7." In The Daily Study Bible Series, 87. Philadelphia: Westminster, 1975.

Burge, Gary M. "John.” In Evangelical Comentary on the Bible, edited by Walter A Elwell, 843. Second. Michigan, 1990.

Jonch, Christian. "Yesus Sebagai Guru: Studi Injil Yohanes." Veritas 8, no. 2 (2007): 257-276.
Sidjabat, Binsen S. "Meretas Polarisasi Pendidikan Kristen." Indonesian Journal of Theology 7, no. 1 (2019): 7-24.

Subagyo, Andreas B. Pengantar Riset Kuantitatif $\mathcal{E}$ Kualitatif Termasuk Riset Teologi Dan Keagamaan. Pertama. Bandung: Yayasan Kalam Hidup, 2004.

Sutoyo, Daniel. "Yesus Guru Agung." Antusias 3, no. 5 (2014): 64-65.

Tenney, Merril C. Survei Perjanjian Baru. Ketiga. Malang: Gandum Mas, 1995.

Zaluchu, Sonny Eli. "Metode Penelitian Di Dalam Manuskrip Jurnal Ilmiah Keagamaan.” Jurnal Teologi Berita Hidup 3, no. no 2 (2021): 249-266. 